\title{
Do Syrian refugees a real impact on local unemployment in Turkey?
}

\author{
Emin Çakılcı'
}

\begin{abstract}
Syrian civil war has caused a forced massive immigration into neighbour countries. Almost six billion people has spreaded out neighbour countries as being refugees. Since the start of the war in March 2011, three billion syrian people's have passed the borders as being refugees to Turkey. Turkey has the biggest share on the World of this massive emigration. Syrian refugees firstly settled in camps near the borders and after filling the camps they spread out across the country. Most of them have started to working informally at seconder sector; therefore they have been invisible competitors for native employees. In this study, the effects of Syrian refugees as employees on local unemployment were discussed. Outcomes show us Syrian refugees have a real impact on native unemployment, especially in the informal sectors. In cities where Syrian refugees have settled, local unemployment rates have inclined; because of this, many native employees have lost their jobs.
\end{abstract}

Keywords: Syrian refugees, Immigration, Turkey, Labour, Unemployment, Informal working.

\section{INTRODUCTION}

The issue of migration deals not only with the receiving states, but also with all the geographical locations where globalization is felt or intensively experienced; nowadays it is the most important thing for all countries. Almost every country in the world is affected by migration. Particularly in the second half of the twentieth century, the world has witnessed mass population movements, and the immigrant population has rapidly increased over the last half century. As a matter of fact, according to the United Nations data, it is expected that the number of international immigrants in the world will reach to 405 million by 2050 if they continue to increase as rapidly as in the last 20 years. The total number of international migrants globally has grown faster than the world's population. From the result of this faster growth rate, the share of migrants in the total population reached \%3.3 in 2015, up from \%2.8 in 2000 (UN, 2016: 21)

Actually Turkey, being a bridge between Europe and Asia, has been always a hosting and transition country for immigrants in history. Turkey has a long-established tradition of immigration, which opens its doors to immigrants in terms of geographical location, protects those in need and is respected by the world public opinion. In this sense; in 1492, tens of thousands of Jews were rescued from Spain by ships and brought to the Ottoman Empire territory. [In 1709, with the group of about 2 thousand accompanied by King Charles of Sweden, he took refuge in the Ottoman Empire; Prince Lajos Kossuth and 3,000 Hungarians, In the Ottoman Empire, after the 1917 Bolshevik Revolution, Vrangel demanded protection from the Ottoman Empire with about 135 thousand people. During the Republican period, about 1,185,000 people arrived from Greece, Balkans and Germany between 1922 and 1945. The arrival of some 900,000 people from Iraq, Bulgaria, Bosnia and Kosovo between 1988 and 2000 has been among the most concrete examples

\footnotetext{
${ }^{4}$ Ph.D., emincakilci@yahoo.com
} 
of Turkey's current migration history. In short, Turkey has hosted millions of people. (GDI, 2016:14)

The term transit countries refers to persons who enter the country through legal or illegal means to reach the target country from the source countries and use this country as a transit point, leaving soon after. Due to its geographical position and the political, social and economic problems in neighboring countries, Turkey is a transit country, used as a bridge for accessing the developed European countries of both the target country and foreign nationals. Having long land and sea borders as well as being in a position of bordering many neighbors proves Turkey's potential in the field of migration.

In fact, a total of 2,377,439 people emigrated to Turkey between 1923 and 2000. However, when approximately 671,000 migrants (Bulgarian, Bosniak, Afghan, Peshmerge, Iraqi) returned to home after the improvement of the events in their countries. The number was reduced, with 1.705.939 migrants in Turkey (Deniz, 2014:199). As you can see, Turkey has not been a country that has received immigration since the foundation of its republic. The total migration in 70 years is an extremely low figure of just 1.7 million; because of this, Turkey has not enough experience with migration and its problems consequences.

Before the civil war, it is estimated that the total population of Syria was 22.5 million and the official language of Syria is Arabic. The capital is the city of Damascus, which has a population of 1.7 million. Aleppo, with a population of 4.6 million, is Syria's largest city. The average life expectancy at birth in Syria is 72 years for men and 77 years for women. Syria has a very young population. Approximately 35 percent of the total population in 2012 was under 15 years of age. In the same year, the median age was 22. According to World Bank estimates, Syria's GDP per capita (GDP) was US \$ 3.289 in 2012. Syria's main exports are agricultural products and petroleum. About $\% 17$ of the Syrian workforce is in agriculture, $\% 16$ in the industrial sector and $\% 67$ in the service sector (AFAD, 2013:12).

Migration can be described as moving from one country to another county to settlement, simply. Migration can have two motivations; one of them being desire, and the other coming from enforcement. The Syrian civil war, from the date of beginning in March 2011, has caused a massive migration process, according to United Nations (UN) data. Almost 6 billion people have emmigrated to neighboring countries as refugees. The biggest proportion of this massive migration has been directed toward Turkey, for its historical reputation as a transit point. Only 2.6 million Syrian refugees had passed the Turkish borders by the end of 2015. Nowadays around 3 million Syrians have arrived in Turkey and they make up \%3.5 of Turkey's current population (ICG, 2016: i). Firstly, 1 in 3 refugees have settled in goverment directed camps and the rest have settled in several urban cities in eastern Turkey.

The state of Turkey has been providing temporary protection to Syrian refugees from the beginning of this migration informally, but near time legal proceed has been completed and temporary protection legally arranged.

Temporary protection may be described as an urgent and temporary protection implemented by the choice of the Council of Ministers in situations where there is a gigantic influx to the degree that the viable use of the system of individual universal assurance applications is impractical.

Temporary Protection issues was regulated by Article 91 of Law No. 6458. Its regulates the protection to be provided to strangers who came to our borders or passed our borders in order to find urgent and temporary protection, entered into force on 22 October 2014 in Turkey.

The legal frame determines the rules of rights and obligations for the Syrians refugees. Education, employment facilities, social aid and support, and similar services are presented to the Syrian with regards to the law.

The temporary protection provides to refugees: boundless free health care, entrance to education by joining people in public school, and working allowance. Just 10,227 Syrians have been 
Çakıllc1, E. (2017). Do Syrian refugees a real impact on local unemployment in Turkey?. Journal of Human Sciences, 14(2), 1207-1214. doi:10.14687/ihs.v14i2.4393

granted working allowance from the start of the migration to the end of 2016. They can likewise sign contracts with public administrations for power, water, gas, television, and communication.

\section{THE CHANGE IN PARAMETRES IN THE CITIES WHICH SYRIAN REFUGEES HAVE SETTLED}

Syrian refugees who entered Turkey have been registered and continue to be registered. In 2015, 984.263 Syrian refugees were registered and the total number of biometric registrations of Syrian citizens who were temporarily protected under the year was 2.503.549. The total number of Syrians in Turkey was an estimated total of 2.75 million by the end of 2016; in addition to that, 300,000 will be hosted in the official refugee camps managed by the Disaster and Emergency Management Presidency (AFAD) and 2.45 million will live within host communities. Figure 1 show us the total number of Syrian refugees under temporary protectection in Turkey in the years 20112016.

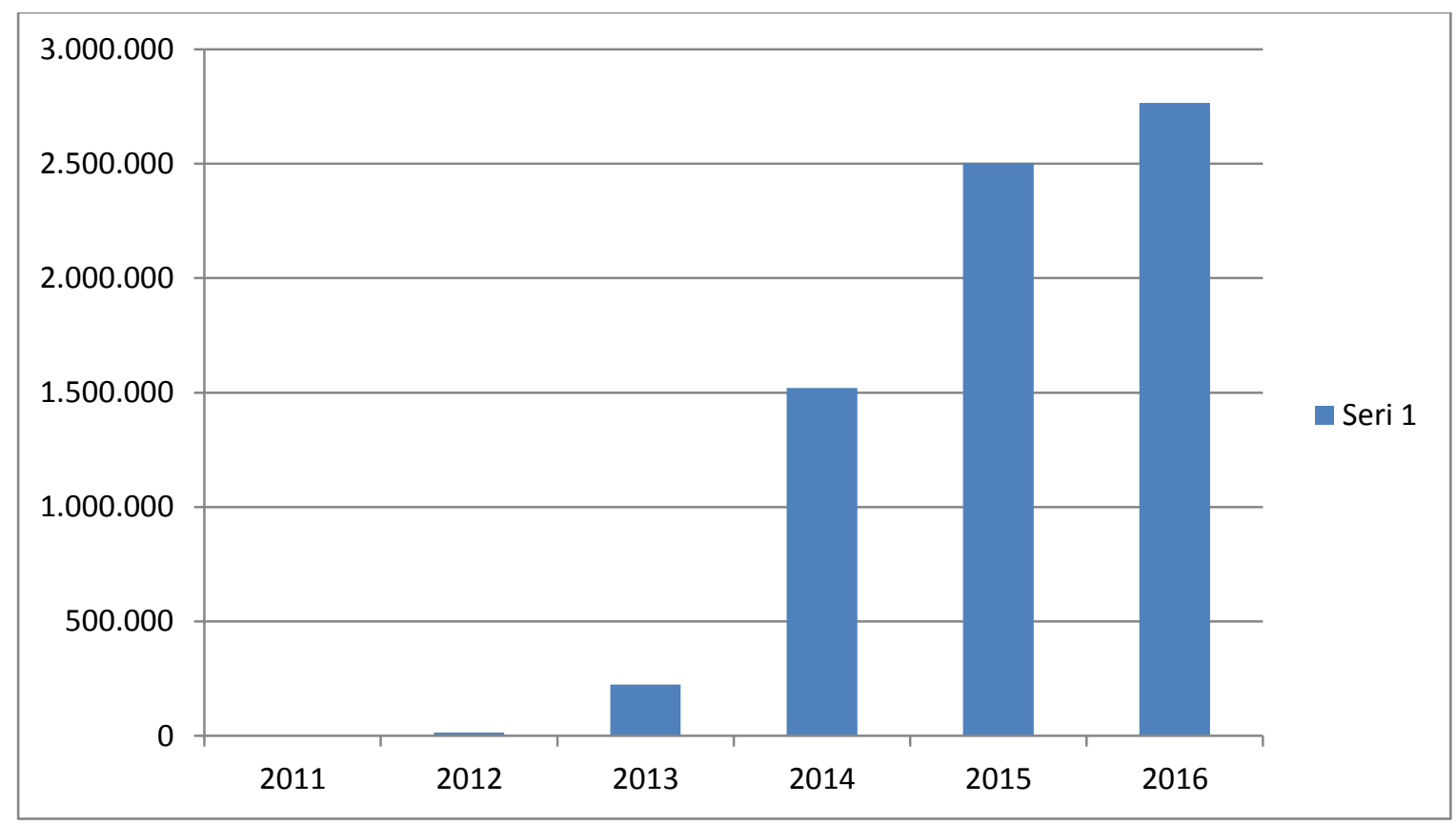

Figure: 1: Number of Syrian Citizens Temporarily Protected by Turkish Government. Source: collected from (GDI, 2016: 85) and (UNHCR, 2016: 4)

There are 2.75 million Syrians under "temporary protection", 90 per cent of them settled around the country, mostly in provinces bordering Syria and the lower income outskirts of Istanbul, Izmir and Ankara. 10 percent of them (267.243 sryians) setteled in 29 camps that have been founded ten cities nearby the border: Hatay, Gaziantep, Şanlıurfa, Kilis, Mardin, Kahramanmaraş, Osmaniye, Adiyaman, Adana, Malatya (GDI, 2016: 88)

Figure 2 shows the top ten cities that are hosting Syrian refugees in Turkey. Istanbul, Şanliurfa, Hatay, Gaziantep, Adana, Mersin, Kilis, Bursa, İzmir and Mardin have hosted the most refugees by total number. 


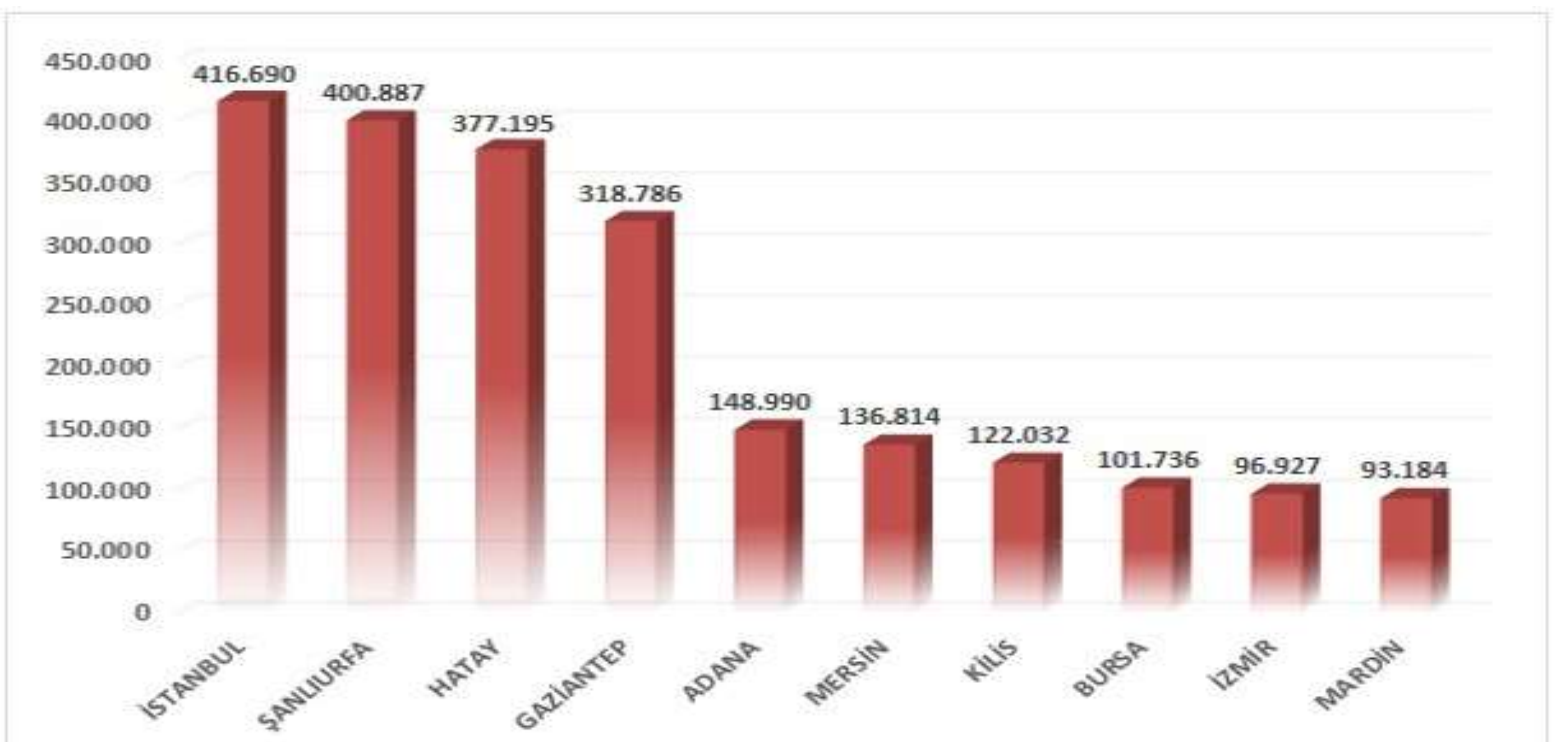

Figure 2: Top 10 cities hosting Syrian refugees under temporary protection 2016 Source: GDI, http://www.goc.gov.tr/icerik6/gecici-koruma_363_378_4713_icerik

Figure 3 shows the top 10 Turkish cities hosting Syrian refugees by percentage as a part of total population. These cities' prior and posterior term unemployment ratios after Syrian immigration is quite important for the study.

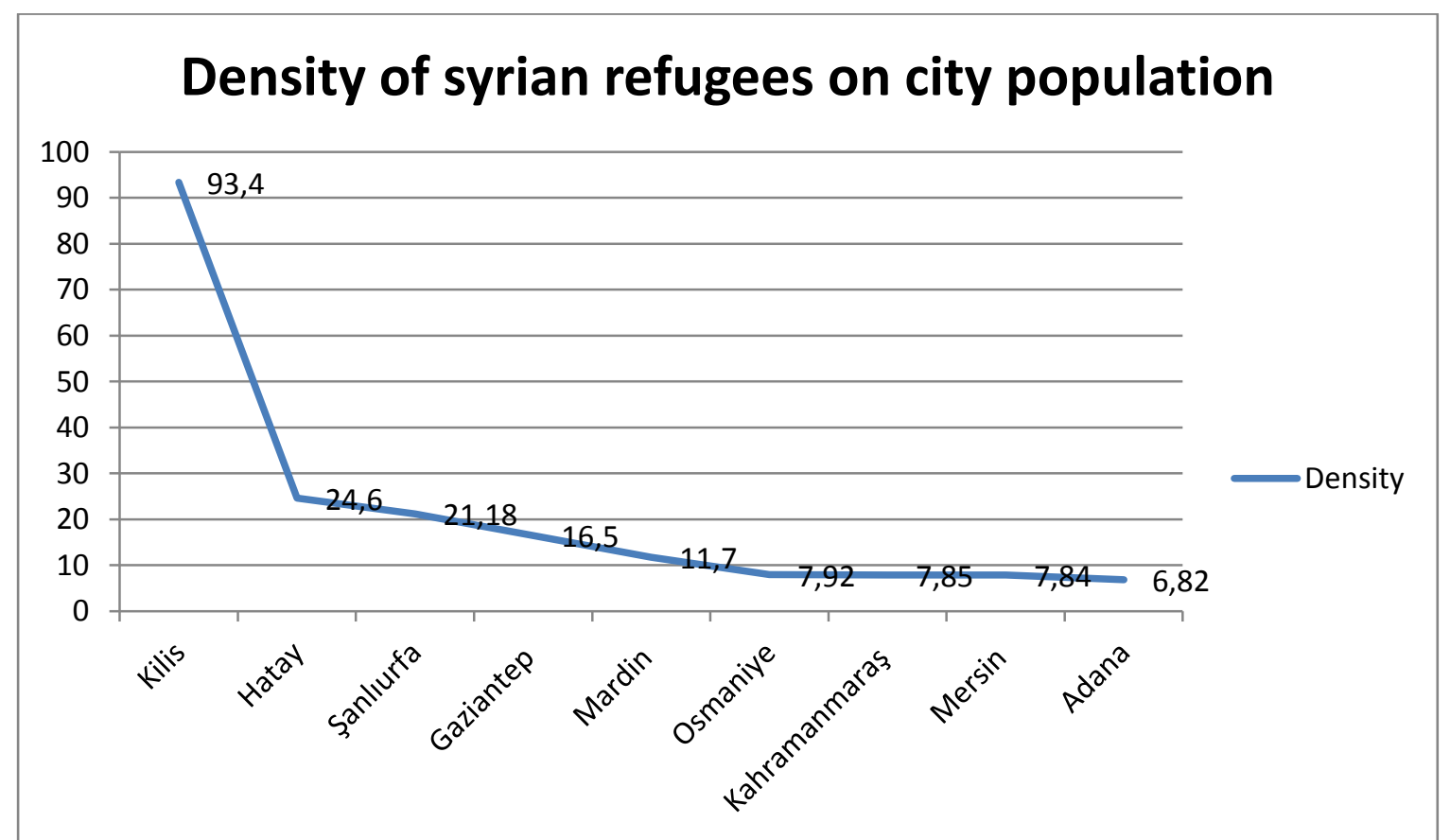

Figure 3: Top ten Cities with regard to Syrian Density in its Population 2016 Source: GDI http://www.goc.gov.tr/icerik6/gecici-koruma_363_378_4713_icerik

However, more than half of Syrian migrants have been living in four cities: İstanbul, Şanliurfa, Hatay, Gaziantep; their number is small with regard to the total population. Refugees have a more extreme effect in small cities with regard to population density such as Kilis, Hatay, Şanliurfa. Remarkably, refugee population ratios amount up to 93.4 percent in Kilis. Consequently, in these cities, which are shown in Figure 3, the native labor force and employment market are extremely affected by Syrian refugees. Syrian refugees are not officially permitted to work in Turkey 
as registered workers up to January 2016. The Turkish labor market offers informal employment types for Syrian refugees because they do not know the Turkish language and are considered to be unskilled workers.

Of the Syrian refugees in the labor force, the gender composition of the consists of $\% 53.1$ males and \%46.9 females, so there is a unbalanced composition in favour of males. The population in working age defined literally as, the number of people being on 15-64 years old intervally and have no excuses. This interval is important for determining of the countries labor force and so Syrian refugees extremly being in working age $(\% 60)$. There is another factor that shows labour force qualification: education level. Syrians refugees education level and skills are very low and inadaquate; about \%85 of them have less than a high school degree. However, the educational profile of refugees shows remarkable similarity to the native population's education level in major areas where refugees have settled. Resulting from the fact that Syrians and natives in these areas have similar education levels, it's probable that the refugees may be a substitute for native workers in labor market in Southeastern Turkey.

There are several reasons for the low number of work permit applicants. Employers need to apply for work permits for the refugees. Preparing the application document is complicated to refugees and the labour agencies and lawyers employed to assist in the process come with a noteworthy cost. Various professions are exempted; it is difficult for professionals to get the required equivalence certificates of their diplomas from the Turkish Higher Education Board or documents from Syria, and there is a general lack of information about work permit procedures. Finally the Turkish language barrier is a major problem for refugees seeking employment in Turkey (ICG, 2016: 8)

The informal employment ratio in turkey is \%34.6 as of September 2016 (TURKSTAT). This number shows that informal work has an important role in the labor market. Syrian refugees are increasing these ratios in local labour markets by supplying cheap and informal workpower. Hence, wages have gone down and informal employment has increased against natives.

Unemployment ratios in Turkey generally are figured in below. At the begining of the period, the unemployment rate is $\% 8.4$ and then starts to decline. The lowest ratio is seen in the 2012 as $\% 9$, then ratios turn up contionusly and highest ratio is realized at 2015 as $\% 10.3$. It is clear that 2012 is the b.e point at unemployment. This stiuation can be explained with 2012 being the beginning date of the Syrian migration to Turkey. There is a huge effect of Syrian refugees on the general unemployment level in Turkey.

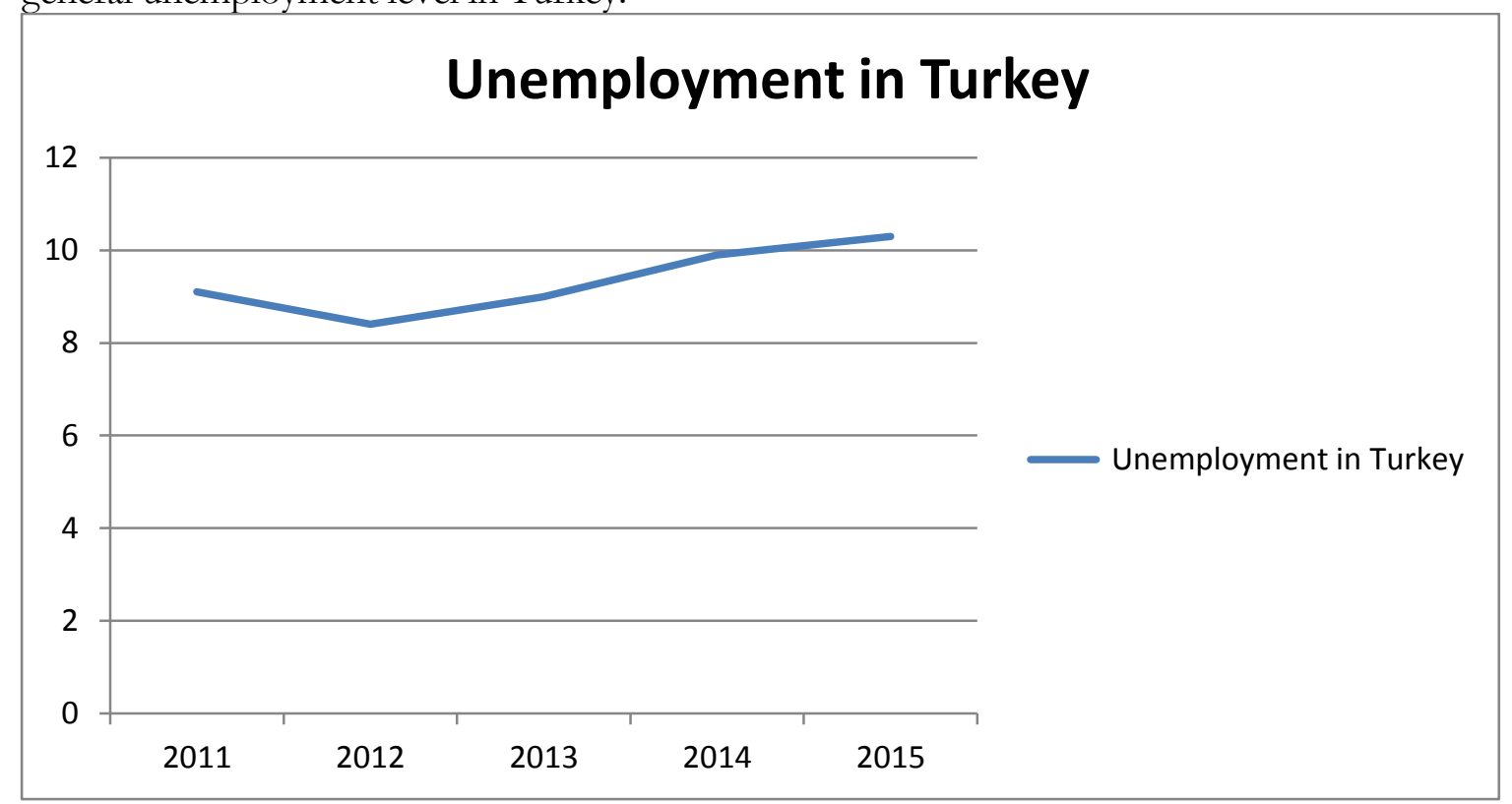

Figure 4: Unemployment ratios in Turkey 2011-2015 Source: TURKSTAT LFS survey 
Kilis city has the greatest density of Syrian refugees with regards to its population, followed by Hatay and Şanluurfa respectively. These cities' prior and later rates of unemployment shows the affect of Syrian refugees on the labor market. These selected three cities' labour force statistics and internal migration datas have been collected, surveyed and presented in the graphics on the following pages. There are many studies and field surveys about these three cities' positions on the impact of Syrian refugees. ${ }^{2}$

Figure 5 shows the selected cities' unemployment ratios yearly. All three cities' unemployment curves are similar. These curves go into decline in 2012, then start to inçline. It is clear that the year 2012 is the b.e point for unemployment. The year 2012 is the date of Syrian refugees penetrating selected cities. Hence, Syrian refugees have a huge effect on local unemployment on selected cities; furthermore, the selected cities' local unemployment ratios are much higher than the country's general ratios.



Figure 5: Unemployment in selected cities which hosted the highest proportions of Syrian refugees in Turkey Source: TURKSTAT LFS surveys, www.turkstat.gov.tr./lfs ${ }^{3}$

Selected cities' net internal migration ratios is an important measure for analysis. This ratio shows the domestic movement of native people internally. People migrate domestically with several aims, like escaping unemployment or violence, seeking better education, etc. These cities typically have negative net migration ratios. Figure 6 shows that all of the lines have similar shapes; prior to the migration period, the lines are horizontal and constant. From the date of 2012, the line start to decrease rigidly and reaches the lowest level at 2013. It's clear that years 2012 is the b.e point on internal migration. We can say that Syrian refugees have dramatically affected domestic migation of native populations.

\footnotetext{
2 See, Bal (2015), Deger(2016), Lordoğlu(2016), Paksoy(2016), ORSAM-TESEV(2015)

${ }^{3}$ First three years datas presented by province based on the other hand last two years datas presented regional based as TRC1, TR63 and TRC2 due to TURKSTAT's new classification arrangements
} 
Çakıllc1, E. (2017). Do Syrian refugees a real impact on local unemployment in Turkey?. Journal of Human Sciences, 14(2), 1207-1214. doi:10.14687/jhs.v14i2.4393

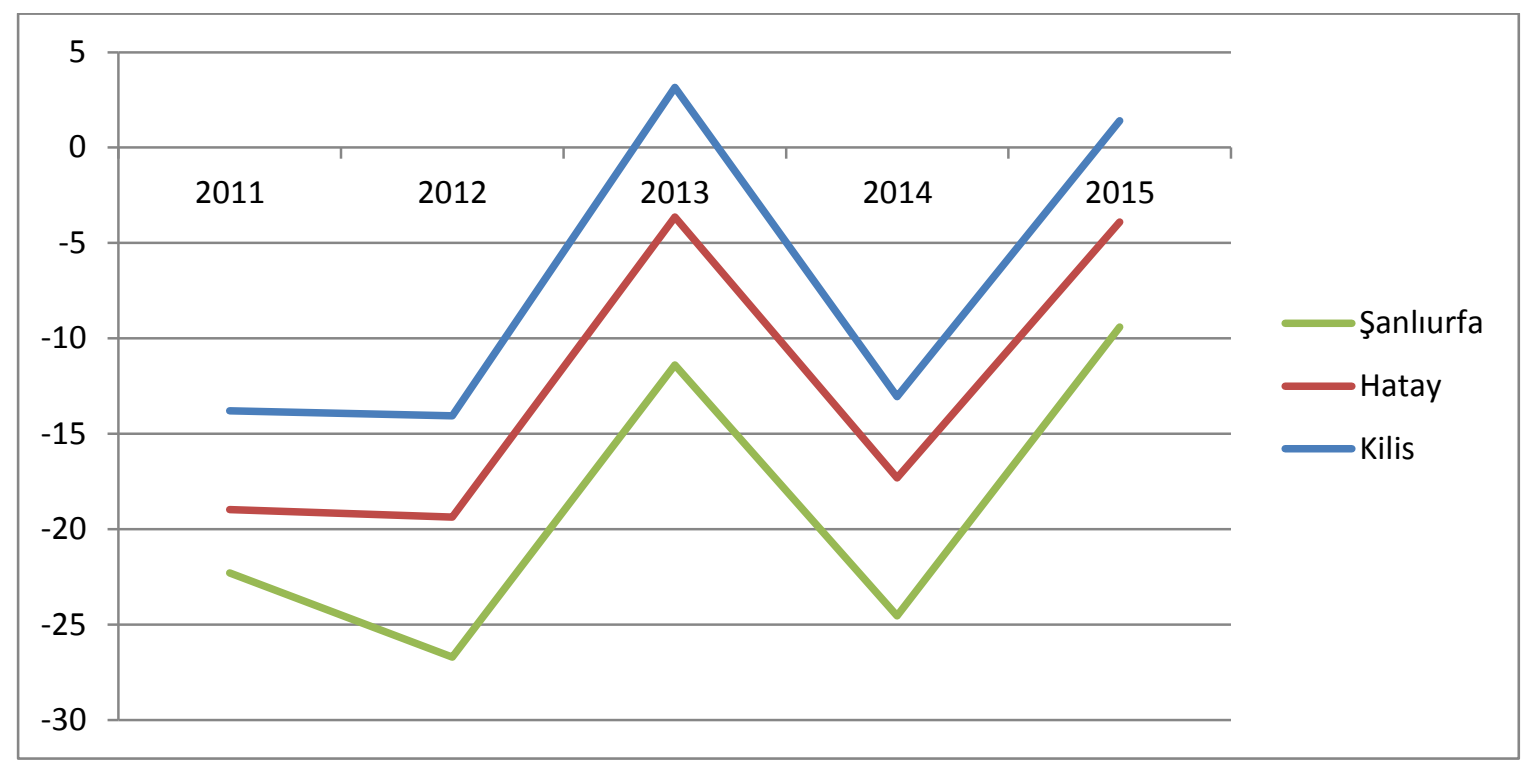

Figure 6: Net internal migration rates for natives internally (foreigners and Syrian refugees excluded) source: TURKSTAT internal migration datas, www.turkstat.gov.tr.

\section{CONCLUSION}

Study outcomes show clearly that the Syrian immigration process has caused unemployment and internal migraiton of native employees. 2012 is considered, for analysis purposes, to be the starting point of the massive Syrian migration. Syrian started to flee in March 2011; just one year later, all parameters have been seriously affected. From this date, all discussed parameters started to show a dramatic increase. There is a remarkable increase in unemployment for native employees related directly to the inflow of Syrian migrants; as a consequence of this, internal migration ratios are in constant flux. Otherwise, Turkey consistently has a great informal employment ratio, estimated in September 2016 to be \%34.6 by TURKSTAT. Syrian refugees have increased local informal employment ratios seriously by supplying cheap labor.

Syrian refugees have a great affect on the local labour market by supplying cheap and informal workpower. Immigration has had a significiant impact on native workpower, increasing unemployment. Hence, the native labour internal migration ratio is affected seriously by Syrian refugees. City based local ratios and country based general ratios have differ from each other radically. Cities whose populations consist of significiant numbers of Syrian refugees have much more unemployment and net internal migration ratios than countries.

\section{REFERENCES}

AFAD (2013) "Syrian Refugees in Turkey, 2013: Field Survey Results," Turkish Directory of Disaster and Emergency Management, www.afad.gov.tr Online 10 March 2016

AFAD (2014) Populaiton Influx from Syrian to Turkey life in turkey as a syrian guest 2014, Ankara, 2014, www.afad.gov.tr. Online 15 March 2016

AFAD (2016) Turkey Immigration report 2015, Turkish Directory of Disaster and Emergency Management, Publishing no: 34, April 2016, Ankara- Turkey

BAL, B. C., AKKÖK, A., SERIN, H.(2015) "Suriyeli Mültecilerin Mobilya Sektörü İsgücü Üzerine Etkileri; Kahramanmaraş İli Örneği” Selçuk-Teknik Dergisi, [S.l.], pp. 439-451, ara. 2015. $<$ http://sutod.selcuk.edu.tr/sutod/article/view/247>. Online: 02 May 2016

DEĞER, Ç., Çalışkan, E.T. and Aydoğmuş, O. (2016) "Population Displacement Effect of Refugees in Turkey: An Input-Output Model Based Analysis", TISK-AKADEMI, Cilt 11, Say1 22, 2016/II, Ankara, Eylül 2016. pp. 238-249 
DENIZ, T. (2014) “Uluslar Arasi Göç Sorunu Perspektifinde Türkiye”, TSA / YIL: 18 S: 1, April 2014 pp. $175-204$.

GDI (2016) 2015 Turkey migration report, Republic of Turkey General Directorate of Immigration. Online 10 September 2016

ICG (2016) Turkey's Refugee Crisis: The Politics of Permanence, Europe Report No241 | 30 November 2016. Online 10 December 2016

LORDOGLU K. and Aslan, M. (2016) "En Fazla Suriyeli Göçmen Alan Beş Kentin Emek Piyasalarında Değişimi: 2011-2014”, Çalışma ve Toplum, 2016/2, pp.789-808. Online 15 September 2016

ORSAM-TESEV (2015) Suriyeli Sı̆̆ınmacıların Türkiye'ye Etkileri, Rapor No: 195, Ankara, Ocak 2015. tesev.org.tr/wp-content/uploads/.../Suriyeli_Siginmacilarin_Turkiyeye_Etkileri.

Online 10 May 2016

PAKSOY, H.M., Koçarslan, H., Kılınç, E. and Tunç, A. (2015) "Suriyelilerin Ekonomik Etkisi: Kilis İli Örneğı” Birey ve Toplum Sosyal Bilimler Dergisi, Bahar 2015, Cilt 5, Say1 9, pp 143-173. http://bireyvetoplumdergisi.com/article/view/5000164611 Online 15 may 2016

TURKSTAT Turkish Statistical Institute (TURKSTAT) Labor Force Surveys (LFS)

UNHCR (2016) Turkey 3RP Regional Refugee \& Resilience Plan 2016-2017, www.3RPSyriaCrisis.org Online 10 October 2016

UN (2016) International Migration Report 2015: Highlights, ST/ESA/SER.A/375, NY 2016, www.un.org/.../migration/.../migrationreport Online: 05 May 2016 